\title{
What quantitative mechanical loading stimulates in vitro cultivation best?
}

\author{
Jerry Natenstedt ${ }^{1}$, Aimee C Kok ${ }^{2}$, Jenny Dankelman ${ }^{1}$ and Gabrielle JM Tuijthof ${ }^{1}$ 2* $^{*}$
}

\begin{abstract}
Articular cartilage has limited regeneration capacities. One of the factors that appear to affect the in vitro cultivation of articular cartilage is mechanical stimulation. So far, no combination of parameters has been identified that offers the best results. The goal is to review the literature in search of the best available set of quantitative mechanical stimuli that lead to optimal in vitro cultivation.

The databases Scopus and PubMed were used to survey the literature, and strict in- and exclusion criteria were applied regarding the presence of quantitative data. The review was performed by studying the type of loading (hydrostatic compression or direct compression), the loading magnitude, the frequency and the loading regime (duration of the loading) in comparison to quantitative evidence of cartilage quality response (cellular, signaling and mechanical).

Thirty-three studies met all criteria of which 8 studied human, 20 bovine, 2 equine, 1 ovine, 1 porcine and 1 canine cells using four different types of cultivated constructs. Six studies investigated loading magnitude within the same setup, three studies the frequency, and seven the loading regime. Nine studies presented mechanical tissue response. The studies suggest that a certain threshold exits for enhanced cartilage in vitro cultivation of explants (>20\% strain and $0.5 \mathrm{~Hz}$ ), and that chondrocyte-seeded cultivated constructs show best results when loaded with physiological mechanical stimuli. That is a loading pressure between 5-10 MPa and a loading frequency of $1 \mathrm{~Hz}$ exerted at intermittent intervals for a period of a week or longer. Critical aspects remain to be answered for translation into in vivo therapies.
\end{abstract}

Keywords: Chondrocytes; BMMSC; Compression; Mechanical loading; in vitro; Collagen type II; GAG; Cell therapy

\section{Introduction}

Articular cartilage is a nonlinearly permeable, viscoelastic multiphasic material containing chondrocytes and proteoglycan aggregates (3-10\% of volume) that are surrounded by an extracellular matrix (ECM), whose primary constituents are water with mobile ions (60-85 \% of volume) and collagen type II (10-30 \% of volume) (Fig. 1) (Mow et al. 1999; Schulz and Bader 2007; Khan and Scott 2009; Madry et al. 2010). Damaged articular cartilage presents itself as partial chondral, full thickness chondral or osteochondral defects (Fig. 1). Partial or full thickness lesions show limited ability to regenerate due to its avascular and highly structured nature, which prevents progenitor cells

\footnotetext{
* Correspondence: g.j.m.tuijthof@tudelft.nl

'Department of Biomechanical Engineering, Faculty of Mechanical, Materials and Maritime Engineering, Delft University of Technology, Mekelweg 2, Delft 2628 CD, The Netherlands

${ }^{2}$ Department of Orthopedic Surgery, Academic Medical Centre, Meibergdreef 9, Amsterdam, AZ 1105, The Netherlands
}

and chondrocytes to migrate to the defect-site (Heath and Magari 1996; Zengerink et al. 2006; Khan et al. 2008; Magnussen et al. 2008; Khan and Scott 2009). For osteochondral defects, the subchondral bone plate is breached leading to an inflow of blood containing bone marrowderived mesenchymal stem cells (BMMSCs) that populate the defect site (Khan and Scott 2009; Madry et al. 2011). These cells may differentiate into chondrocytic cells, which in turn can regenerate the ECM (Angele et al. 2003; Bahuleyan et al. 2009). This repair tissue mostly contains collagen type I and degrades over time (Khan et al. 2008; Madry et al. 2011; Hannon et al. 2014). However, newer tissue engineered techniques are clinically applied in which tissue engineered constructs with or without (autologous) cells are used to enhance cartilage regeneration with more hyaline like cartilage as result (Brittberg 2010; Fortier et al. 2011; Hildner et al. 2011; Spiller et al. 2011). Over the last decade, numerous studies have been 


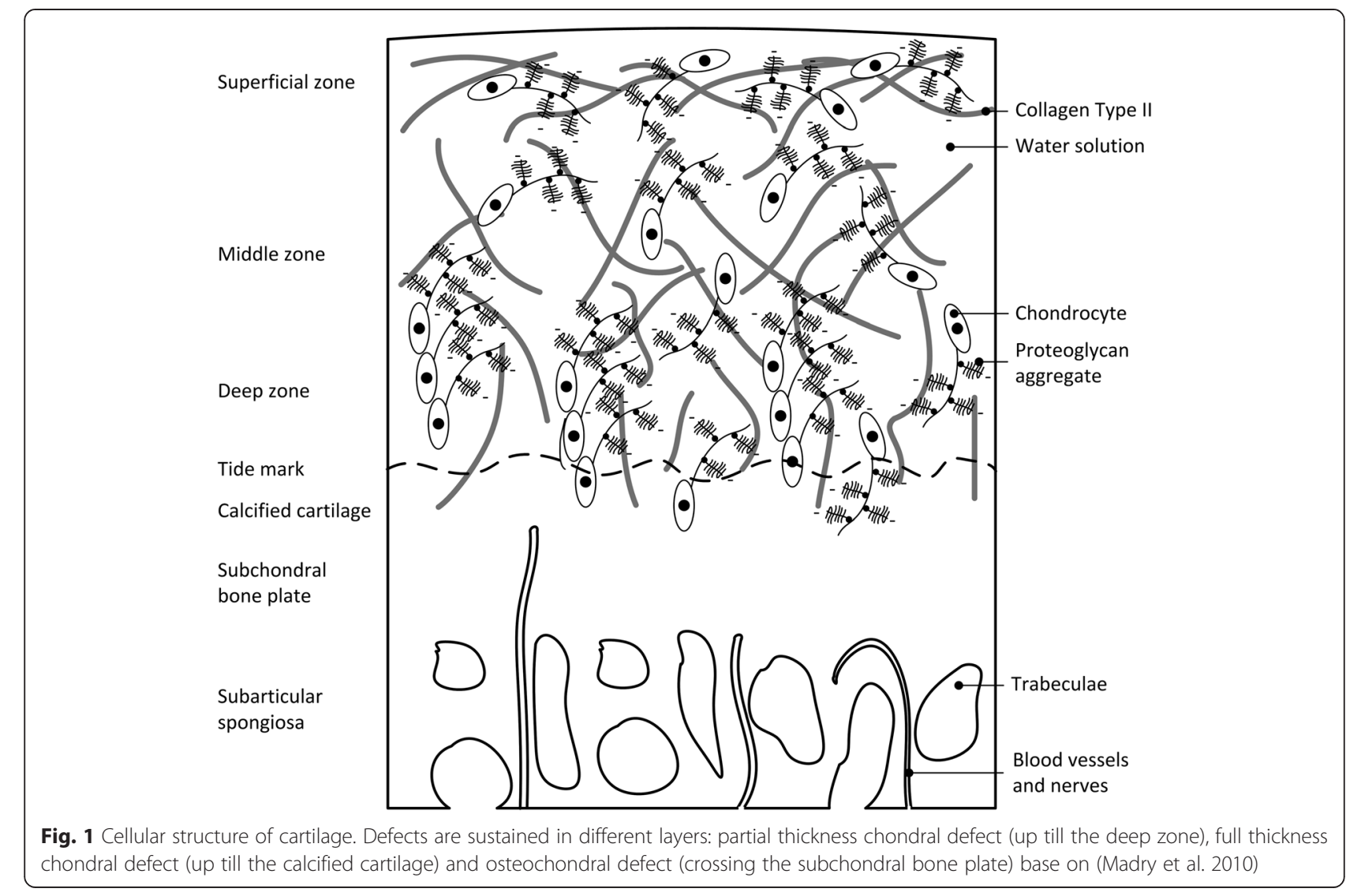

published that unravelled important factors influencing the cartilage regeneration process (e.g. (Chung and Burdick 2008; Khan et al. 2008; Brittberg 2010; Fortier et al. 2011; Hildner et al. 2011; Spiller et al. 2011)).

This review will focus on the mechanical loading to promote cartilage cultivation. Mechanical stimuli promote ECM production (Grodzinsky et al. 2000), increase chondrocyte activity, and aid to protect the ECM temporarily from excessive loading (Mow et al. 1999). Due to its unique composition, cartilage can be loaded up to $18 \mathrm{MPa}$ in vivo, which is up to 15 times the body weight (Darling and Athanasiou 2003; Elder and Athanasiou 2009; Spiller et al. 2011). If an underdeveloped ECM sustains such high loading, it can collapse; and can further deteriorate eventually leading to a full stop in intrinsic repair (Darling and Athanasiou 2003). A similar mechanism is seen when damaged cartilage (with a disrupted ECM) is loaded during gait with physiological values of around 5 times the body weight (van Dijk et al. 2010a, 2010b).

On the other hand, biomechanical intermittent cyclic loading has shown to stimulate regeneration of cartilage tissue (Arokoski et al. 2000; Bonassar et al. 2001; Waldman et al. 2004; Chung and Burdick 2008; Fan and Waldman 2010; Hess et al. 2010; Potier et al. 2010). Tissue engineering studies show that dynamic compression increases cartilage in vitro cultivation rather than static compression
(Schulz and Bader 2007; Elder and Athanasiou 2008, 2009; Mizuno and Ogawa 2011). Important loading parameters appear to be the magnitude, frequency and duration (Ikenoue et al. 2003). So far, no combination of parameters has been identified that offers the best result in in vivo regeneration. Unfortunately, a first search in the literature indicated that none of the retrieved in vivo studies provided quantitative values to identify this combination. Therefore, the goal of this study is to review the literature in search of the best available set of quantitative mechanical stimuli that increase cartilage in vitro cultivation; and possibly deduct suggestions for in vivo cartilage regeneration.

\section{Review \\ Methods}

The databases Scopus and PubMed where used to survey the literature. The following keywords and synonyms were used to retrieve candidate studies: (Mechan* OR Biomech*) AND (load* OR loading OR stimulat* OR compress" OR shear OR forces) AND articular cartilage $A N D$ (repair OR regeneration OR healing). Both original and review papers were included from 1980 until April 18th 2015 and the search was limited to English language. The in- and exclusion criteria were formulated based on strict interpretation of the research question. 


\section{Inclusion criteria}

Studies were included if they:

- Studied dynamic loading.

- Harvested either chondrocyte or BMMSC cultures from larger animal models (canine, bovine, equine, porcine, human). Larger animals provide a closer environment and metabolism to the human cartilage case (Chu et al. 2010).

- Provided quantitative values of the applied mechanical stimuli (loading magnitude, frequency, type and regime).

- Provided quantitative values of the effect on the cartilage quality response (e.g. cellular or mRNA response in terms of increased percentage).

\section{Exclusion criteria}

Studies were excluded if they only:

- Used computational methods to simulate the mechanical properties or regenerating capabilities of cartilage.

- Determined the mechanical properties of cartilage (e.g. stiffness or elastic strain limit).

- Presented operative techniques to promote cartilage healing (e.g. grafting and graft-ingrowth, arthroplasty, or microfracturing).

- Studied in vivo loading to stimulate cartilage, for example by specific physical therapy protocols, and did not provide quantitative data on the mechanical stimuli and/or effect on the cartilage quality response.

- Studied non-articular cartilage (e.g. cartilage of the ear).

- Examined the effect of non-mechanical factors (e.g. hormonal, chemical, or electrical) that can stimulate cartilage cultivation or regeneration.

- Harvested chondrocytes or stem cells from small animals (e.g. rodent) (Chu et al. 2010).

- Performed continuous static compression as loading regime.

From the included studies, the cell donor and culture, the construct, the additives, the type of loading (hydrostatic compression or direct compression), the loading magnitude, the frequency and the loading regime (duration of the loading) were documented as input parameters, and the quantitative evidence of cartilage quality response (cellular, signaling and mechanical responses) was documented as output parameter. Unfortunately, variety in testing conditions such as cell source, cultivated constructs, and the chosen cartilage quality response parameters only allowed for a qualitative comparison. To enhance comparison, the applied loading regime is presented in one format: the frequency, the total time of loading per day, the total number of days and total loading hours.
Additionally, the loads were mostly expressed in pressure ( $P$ or $\sigma$ equals force per area expressed in $\mathrm{Pa}$ ) (Shepherd and Seedhom 1999; Darling and Athanasiou 2003). However, some studies use the strain $(\varepsilon)$, defined as the percentage of cartilage thickness decrease. To enhance uniformity, the strain values were converted into pressure values using the formula for linear elastic materials:

$$
\sigma=E \cdot \varepsilon
$$

Where $E$ is the Young's modulus, which is a material property, and $\sigma$ is the compression load expressed in $\mathrm{Pa}$. Since cartilage is a viscoelastic multiphasic material (Mow et al. 1999), multiple parameters are needed to describe its material behaviour. In this study, an approximation of the Young's modulus was used: the 'instantaneous' compressive modulus of cartilage $\left(E_{c}\right)$ (Shepherd and Seedhom 1999). Substituting $E_{c}$ and $\varepsilon$ in Equation (1) gives the compression load. The value of $E_{c}$ depends on the joint donor site (Shepherd and Seedhom 1999). To this end, the range of values for the human knee joint (between 6 and $12 \mathrm{MPa}$ ) was filled out in Eq. (1) together with the applied strain to calculate $E_{c}$ for studies that used the human knee, the bovine and canine stifle joint as donor sites (Shepherd and Seedhom 1999). In a similar fashion, the range of values for the human ankle (between 11 and $19 \mathrm{MPa}$ ) was filled out for bovine or canine metatarsal donor joints (Shepherd and Seedhom 1999).

Finally, this review presents the changes found in cellular, signaling and mechanical response due to the mechanical stimuli, which were indicated as an increased $(+)$ or decreased (-) response compared to controls or as no change or similar $(=)$ (Tables $1,2,3,4,5)$.

\section{Results}

After a first title and abstract scan of the 836 hits combined from Scopus and PubMed, 106 papers were left to be reviewed completely, which eventually resulted in 33 studies that were eligible for inclusion. Generally, the tissue engineering studies investigated the effect of mechanical stimuli on cultivated constructs at least in one study arm compared to unstimulated controls (Darling and Athanasiou 2003; Mauck et al. 2003). Tables 1, 2, 3, 4, 5 summarize the results.

\section{Cell sources, cultivated constructs and additives}

Two cell sources (chondrocytes and BMMSC) were studied from 6 mammal types: 8 studies used human cells, 20 bovine, 2 equine, 1 ovine, 1 porcine and 1 canine. First, 27 studies used chondrocytes as cell source (Tables 1, 2, 3, 4). Chondrocytes are responsible for the production of the ECM (Meachim and Stockwell 1973; Buckwalter and Mankin 1998; Cohen et al. 1998), since they are likely to synthesize collagen type II and proteoglycans (Schulz and 
Table 1 Results on changes in cellular, signaling and/or mechanical response to explants for hydrostatic and direct compression (Fig. 2). PG is proteoglycan; MMP is matrix metalloproteinases; \# is number; h is hours; h/day is hours per day; - is decrease or inhibition; = is no change or status quo; + is increase; ++ is highest increase. ${ }^{*}$-symbol implies pressure converted from strain, which is added in brackets

\begin{tabular}{|c|c|c|c|c|c|c|c|c|c|}
\hline Study & $\begin{array}{l}\text { Cell source, cultivated } \\
\text { construct, additive(s) }\end{array}$ & Magnitude (MPa) & Freq $(\mathrm{Hz})$ & Loading (h/day) & Loading (\# days) & Loading (total h) & $\begin{array}{l}\text { Culture composition } \\
\text { (change }-,=,+ \text { ) }\end{array}$ & $\begin{array}{l}\text { mRNA response } \\
\text { (change }-,=,+ \text { ) }\end{array}$ & $\begin{array}{l}\text { Other findings } \\
\text { (change }-,=,+ \text { ) }\end{array}$ \\
\hline \multicolumn{10}{|l|}{ Hydrostatic compression } \\
\hline \multirow{4}{*}{$\begin{array}{l}\text { Parkinnen } 1993 \\
\text { (Parkkinen et al. 1993) }\end{array}$} & Bovine & 5 & 0.5 & 1.5 & 1 & 1.5 & + PG synthesis & & \\
\hline & Explant & & 0.25 & & & & & & \\
\hline & Fetal calf serum & & 0.05 & & & & $=P G$ synthesis & & \\
\hline & & & 0.0167 & & & & & & \\
\hline \multicolumn{10}{|l|}{ Direct compression } \\
\hline \multirow[t]{6}{*}{ Li 2013 (Li et al. 2013) } & \multirow{6}{*}{$\begin{array}{l}\text { Young Bovine Bruised } \\
\text { Explant Serum free medium, } \\
20 \mathrm{~g} / \mathrm{ml} \text { ascorbic acid }\end{array}$} & $0.6-1.2^{*}(10 \%)$ & 0.5 & 4 & 4 & 16 & $+P G$ synthesis & + aggrecan & \multirow{6}{*}{$\begin{array}{l}\text { Control show better } \\
\text { results compared to } \\
\text { bruised explants }\end{array}$} \\
\hline & & & & & & & & + collagen II & \\
\hline & & $1.2-2.4^{*}(20 \%)$ & & & & & ++ PG synthesis & ++ aggrecan & \\
\hline & & & & & & & & ++ collagen $\|$ & \\
\hline & & $1.8-3.6^{*}(30 \%)$ & & & & & $+P G$ synthesis & + aggrecan & \\
\hline & & & & & & & & = collagen $\|$ & \\
\hline \multirow{2}{*}{$\begin{array}{l}\text { Okuda } 2013 \text { (Okuda } \\
\text { et al. 2013) }\end{array}$} & \multirow{2}{*}{$\begin{array}{l}\text { Young Bovine, Explant } 20 \% \\
\text { Fetal bovine serum; } 50 \text { mg/ } \\
\text { L L-ascorbic acid }\end{array}$} & \multirow[t]{2}{*}{$0.6-1.2^{*}(10 \%)$} & \multirow[t]{2}{*}{1} & \multirow[t]{2}{*}{3.5} & \multirow[t]{2}{*}{5} & \multirow[t]{2}{*}{17.5} & $+s G A G$ & & \multirow{3}{*}{$\begin{array}{l}+ \text { compressive } \\
\text { modulus }\end{array}$} \\
\hline & & & & & & & $+\#$ of cells & & \\
\hline $\begin{array}{l}\text { Torzilli } 1996 \text { (Torzilli } \\
\text { et al. 1996) }\end{array}$ & $\begin{array}{l}\text { Bovine, Explant } 10 \% \text { Fetal } \\
\text { bovine serum; } 50 \mu \mathrm{g} / \mathrm{mL} \\
\text { ascorbic acid }\end{array}$ & 1 & 1 & 24 & 1 & 24 & - PG synthesis & & \\
\hline $\begin{array}{l}\text { Torzilli } 2011 \text { (Torzilli } \\
\text { et al. 2011) }\end{array}$ & $\begin{array}{l}\text { Bovine, Explant } 10 \% \text { Fetal } \\
\text { bovine serum; } 50 \mu \mathrm{g} / \mathrm{mL} \\
\text { ascorbic acid }\end{array}$ & $0.5(10 \%)$ & 0.5 & 24 & 3 & 72 & $=\mathrm{PG}$ content & $=\mathrm{MMP}-3,-13$ & \\
\hline
\end{tabular}


Table 2 Results on changes in cellular, signaling and/or mechanical response to chondrocyte-seeded meshes for hydrostatic and direct compression (Fig. 2). PGA is polyglycolic acid; PEGT/PBT is polyethylene glycol terephthalate/polybutylene terephthalate; Sox9 is the gene that regulates chondrogenic differentiation; \# is number; $h$ is hours; $h /$ day is hours per day; - is decrease or inhibition; = is no change or status quo; + is increase; ++ is highest increase. ${ }^{*}$-symbol implies pressure converted from strain, which is added in brackets; ** loading was performed every other day for $1 \mathrm{~h}$ twice a day with $8 \mathrm{~h}$ rest in between

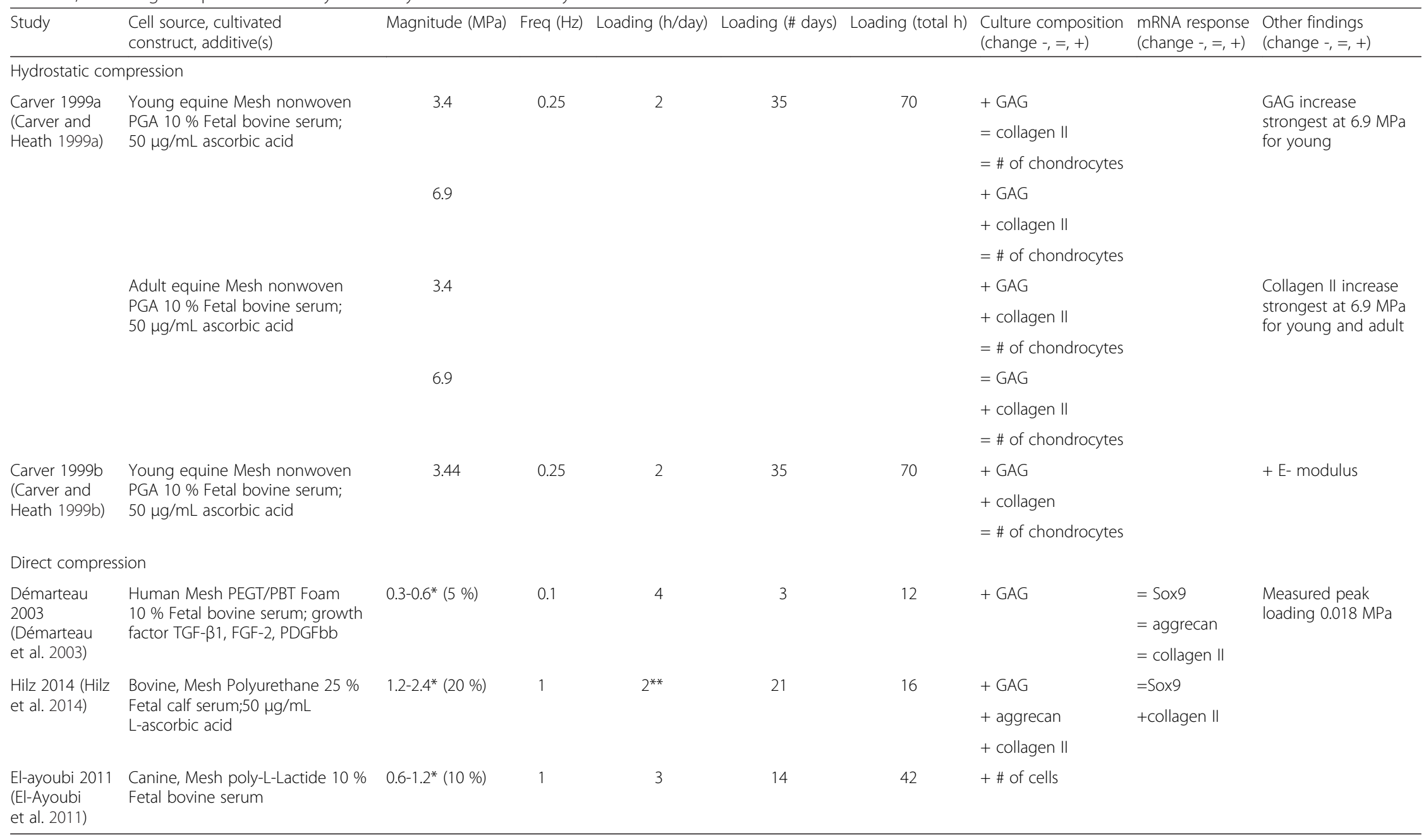


Table 3 Results on changes in cellular, signaling and/or mechanical response to chondrocyte cultivated constructs for hydrostatic compression (Fig. 2). PG is proteoglycan; MMP is matrix metalloproteinases; h is hours; h/day is hours per day:-i is decrease or inhibition; + is increase; ++ is highest increase; = is no change or status quo. ${ }^{*}$-symbol implies pressure converted from strain, which is added in brackets, **-symbol is increased aggrecan only with $4 \mathrm{~h}$

\begin{tabular}{|c|c|c|c|c|c|c|c|c|c|}
\hline Study & $\begin{array}{l}\text { Cell source, cultivated } \\
\text { construct, additive(s) }\end{array}$ & Magnitude (MPa) & Freq $(\mathrm{Hz})$ & Loading (h/day) & Loading (\# days) & Loading (total h) & $\begin{array}{l}\text { Culture composition } \\
\text { (change }-,=,+ \text { ) }\end{array}$ & $\begin{array}{l}\text { mRNA response } \\
\text { (change }-,=,+ \text { ) }\end{array}$ & $\begin{array}{l}\text { Other findings } \\
\text { (change }-,=,+ \text { ) }\end{array}$ \\
\hline \multirow{10}{*}{$\begin{array}{l}\text { Ikenoue } 2003 \\
\text { (Ikenoue et al. } \\
\text { 2003) }\end{array}$} & \multirow{10}{*}{$\begin{array}{l}\text { Human Monolayer } 10 \% \\
\text { Fetal bovine serum }\end{array}$} & \multirow[t]{2}{*}{1} & \multirow[t]{2}{*}{1} & \multirow[t]{4}{*}{4} & \multirow[t]{4}{*}{1} & \multirow[t]{4}{*}{4} & & $=$ aggrecan & \multirow{10}{*}{$\begin{array}{l}\text { Loading of } 16 \mathrm{~h} \text { gave } \\
\text { better results } \\
\text { compared to } 4 \mathrm{~h}\end{array}$} \\
\hline & & & & & & & & = collagen $\|$ & \\
\hline & & 5 & 1 & & & & & + aggrecan & \\
\hline & & 10 & & & & & & $=$ collagen $\|$ & \\
\hline & & \multirow[t]{2}{*}{1} & \multirow[t]{2}{*}{1} & \multirow[t]{6}{*}{4} & \multirow[t]{6}{*}{4} & \multirow[t]{6}{*}{16} & & + aggrecan & \\
\hline & & & & & & & & + collagen II & \\
\hline & & \multirow[t]{2}{*}{5} & \multirow[t]{2}{*}{1} & & & & & + aggrecan & \\
\hline & & & & & & & & ++ collagen II & \\
\hline & & \multirow[t]{2}{*}{10} & \multirow[t]{2}{*}{1} & & & & & ++ aggrecan & \\
\hline & & & & & & & & ++ collagen II & \\
\hline \multirow{12}{*}{$\begin{array}{l}\text { Elder } 2008 \text { (Elder } \\
\text { and Athanasiou } \\
\text { 2008) }\end{array}$} & \multirow{12}{*}{$\begin{array}{l}\text { Young bovine, Agarose gel, } \\
20 \% \text { Fetal bovine serum; } \\
50 \mu \mathrm{g} / \mathrm{mL} \text { L-ascorbic acid }\end{array}$} & \multirow[t]{2}{*}{1} & \multirow[t]{2}{*}{0.1} & \multirow[t]{4}{*}{1} & \multirow[t]{4}{*}{5} & \multirow[t]{4}{*}{5} & $+\mathrm{GAG}$ & & $\begin{array}{l}=\text { Aggregate } \\
\text { modulus }\end{array}$ \\
\hline & & & & & & & $\begin{array}{l}=\text { collagen II and \# } \\
\text { of cells }\end{array}$ & & $=\mathrm{E}$-modulus \\
\hline & & \multirow[t]{2}{*}{5} & \multirow[t]{2}{*}{0.1} & & & & $=G A G$ & & $\begin{array}{l}+ \text { Aggregate } \\
\text { modulus }\end{array}$ \\
\hline & & & & & & & $\begin{array}{l}=\text { collagen II and \# } \\
\text { of cells }\end{array}$ & & $=\mathrm{E}$-modulus \\
\hline & & \multirow[t]{2}{*}{10} & \multirow[t]{2}{*}{0.1} & & & & $+\mathrm{GAG}$ & & $\begin{array}{l}=\text { Aggregate } \\
\text { modulus }\end{array}$ \\
\hline & & & & & & & $\begin{array}{l}=\text { collagen II and \# } \\
\text { of cells }\end{array}$ & & ++ E-modulus \\
\hline & & \multirow[t]{2}{*}{1} & \multirow[t]{2}{*}{1} & & & & $=\mathrm{GAG}$ & & $\begin{array}{l}+ \text { Aggregate } \\
\text { modulus }\end{array}$ \\
\hline & & & & & & & $\begin{array}{l}=\text { collagen II and \# } \\
\text { of cells }\end{array}$ & & + E-modulus \\
\hline & & \multirow[t]{2}{*}{5} & \multirow[t]{2}{*}{1} & & & & $=\mathrm{GAG}$ & & $\begin{array}{l}=\text { Aggregate } \\
\text { modulus }\end{array}$ \\
\hline & & & & & & & $\begin{array}{l}=\text { collagen II and \# } \\
\text { of cells }\end{array}$ & & $=\mathrm{E}$-modulus \\
\hline & & \multirow[t]{2}{*}{10} & 1 & & & & $++\mathrm{GAG}$ & & $\begin{array}{l}++ \text { Aggregate } \\
\text { modulus }\end{array}$ \\
\hline & & & & & & & $\begin{array}{l}=\text { collagen II and \# } \\
\text { of cells }\end{array}$ & & ++ E-modulus \\
\hline
\end{tabular}


Table 3 Results on changes in cellular, signaling and/or mechanical response to chondrocyte cultivated constructs for hydrostatic compression (Fig. 2). PG is proteoglycan; MMP is matrix metalloproteinases; h is hours; h/day is hours per day:i- is decrease or inhibition; + is increase; ++ is highest increase; = is no change or status quo. *-symbol implies pressure converted from strain, which is added in brackets, ${ }^{* *}$-symbol is increased aggrecan only with $4 \mathrm{~h}$ (Continued)

\begin{tabular}{|c|c|c|c|c|c|c|c|c|c|}
\hline $\begin{array}{l}\mathrm{Hu} 2006(\mathrm{Hu} \\
\text { and Athanasiou } \\
\text { 2006) }\end{array}$ & $\begin{array}{l}\text { Young bovine, Agarose gel, } 10 \% \\
\text { Fetal bovine serum; } 50 \mu \mathrm{g} / \mathrm{mL} \mathrm{L}- \\
\text { ascorbic acid }\end{array}$ & 10 & 1 & 4 & 40 & 160 & $\begin{array}{l}=\mathrm{GAG}(\mathrm{no} \text { loss })+ \\
\text { collagen II }\end{array}$ & & $\begin{array}{l}=\text { Aggregate } \\
\text { modulus }\end{array}$ \\
\hline $\begin{array}{l}\text { Mizuno } 2011 \\
\text { (Mizuno and } \\
\text { Ogawa 2011) }\end{array}$ & $\begin{array}{l}\text { Young bovine, Aggregate } \\
\text { pellet, Collagen solution, } 10 \% \\
\text { Fetal bovine serum }\end{array}$ & 0.5 & 0.5 & 24 & 7 & 168 & $+s G A G$ & $\begin{array}{l}+ \text { aggrecan, }+ \\
\text { collagen } I I_{,}+ \\
\text {MMP-3, }-13\end{array}$ & \\
\hline \multirow{2}{*}{$\begin{array}{l}\text { Kawanishi } 2007 \\
\text { (Kawanishi } \\
\text { et al. 2007) }\end{array}$} & \multirow{2}{*}{$\begin{array}{l}\text { Young bovine, Aggregate pellet, } \\
10 \% \text { Fetal bovine serum; 50 } \mathrm{\mu g} / \\
\mathrm{mL} \text { ascorbic acid }\end{array}$} & \multirow[t]{2}{*}{5} & \multirow[t]{2}{*}{0.5} & \multirow[t]{2}{*}{4} & \multirow[t]{2}{*}{4} & \multirow[t]{2}{*}{16} & $+\mathrm{GAG}$ & + aggrecan & \\
\hline & & & & & & & $+s G A G$ & + collagen II & \\
\hline \multirow{2}{*}{$\begin{array}{l}\text { Suh } 1999 \text { (Suh } \\
\text { et al. 1999) }\end{array}$} & \multirow{2}{*}{$\begin{array}{l}\text { Bovine, Monolayer, } 10 \% \text { Fetal } \\
\text { bovine serum }\end{array}$} & \multirow[t]{2}{*}{-0.08 vacuum } & \multirow[t]{2}{*}{0.14} & \multirow[t]{2}{*}{6} & \multirow[t]{2}{*}{1} & \multirow[t]{2}{*}{6} & + PG synthesis & + aggrecan & \\
\hline & & & & & & & $=$ collagen synthesis & $=$ collagen $\|$ & \\
\hline \multirow{10}{*}{$\begin{array}{l}\text { Parkinnen } 1993 \\
\text { (Parkkinen } \\
\text { et al. 1993) }\end{array}$} & \multirow{10}{*}{$\begin{array}{l}\text { Bovine, Monolayer, } 10 \% \text { Fetal } \\
\text { calf serum }\end{array}$} & \multirow[t]{10}{*}{5} & 0.5 & \multirow[t]{4}{*}{1.5} & \multirow[t]{4}{*}{1} & \multirow[t]{4}{*}{1.5} & \multirow[t]{3}{*}{ - PG synthesis } & & \\
\hline & & & 0.25 & & & & & & \\
\hline & & & 0.05 & & & & & & \\
\hline & & & 0.0167 & & & & $=P G$ synthesis & & \\
\hline & & & 0.5 & \multirow[t]{6}{*}{20} & \multirow[t]{6}{*}{1} & \multirow[t]{6}{*}{20} & \multirow[t]{2}{*}{ + PG synthesis } & & \\
\hline & & & 0.25 & & & & & & \\
\hline & & & 0.05 & & & & \multicolumn{2}{|l|}{$=P G$ synthesis } & \\
\hline & & & 0.0167 & & & & \multicolumn{2}{|l|}{ - PG synthesis } & \\
\hline & & & 0.0082 & & & & \multirow[t]{2}{*}{$=P G$ synthesis } & & \\
\hline & & & 0.0034 & & & & & & \\
\hline $\begin{array}{l}\text { Jortikka } 2000 \\
\text { (Jortikka et al. } \\
\text { 2000) }\end{array}$ & $\begin{array}{l}\text { Bovine, Monolayer, } 10 \% \text { Fetal } \\
\text { bovine serum }\end{array}$ & 5 & 0.5 & 20 & 1 & 20 & + PG synthesis & & \\
\hline \multirow{2}{*}{$\begin{array}{l}\text { Smith } 1996 \\
\text { (Smith et al. } \\
\text { 1996) }\end{array}$} & \multirow{2}{*}{$\begin{array}{l}\text { Bovine, Monolayer Ham's F-12 } \\
\text { medium; } 3 \text { \% Fetal bovine serum }\end{array}$} & \multirow[t]{2}{*}{10} & \multirow[t]{2}{*}{1} & \multirow[t]{2}{*}{4} & 1 & 4 & + PG synthesis & + aggrecan & \\
\hline & & & & & & & & + collagen II & \\
\hline $\begin{array}{l}\text { Smith } 2000 \\
\text { (Smith et al. }\end{array}$ & $\begin{array}{l}\text { Bovine, Monolayer, Ham's F-12 } \\
\text { medium }\end{array}$ & 10 & 1 & $2,4,8,12,24$ & 1 & $2,4,8,12,24$ & & $\begin{array}{l}+ \text { aggrecan**, } \\
\text { collagen II }\end{array}$ & $\begin{array}{l}\text { Superior increase } \\
\text { compared to one }\end{array}$ \\
\hline 2000) & & & & 4 & 4 & 16 & & $\begin{array}{l}\text { ++ aggrecan, } \\
+ \text { collagen II }\end{array}$ & od \\
\hline Heyland 2006 & Porcine chondrocytes, Beads & 0.3 & 0.0083 & 6 & 4 & 24 & $+\mathrm{GAG},=$ collagen $\|$ & & \\
\hline $\begin{array}{l}\text { (Heyland et al. } \\
\text { 2006) }\end{array}$ & $\begin{array}{l}\text { alginate, } 10 \% \text { Fetal bovine } \\
\text { serum }\end{array}$ & & & 6 & 7 & 42 & $=\mathrm{GAG},+$ collagen $\|$ & & $=\mathrm{E}$-modulus \\
\hline
\end{tabular}


Table 4 Results on changes in cellular, signaling and/or mechanical response to chondrocyte cultivated constructs for direct compression (Fig. 2). OA is osteoarthritis; MMP is matrix metalloproteinases; PG is proteoglycan; $h$ is hours; $h /$ day is hours per day; - is decrease or inhibition; + is increase; ++ is highest increase; $=$ is no change or status quo.

${ }^{*}$-symbol implies pressure converted from strain, which is added in brackets, ${ }^{* *}$-symbol is increase only present $12 \mathrm{~h}$ post stimulation, $\wedge$-symbol is increase only present after $6 \mathrm{~h}$ post stimulation

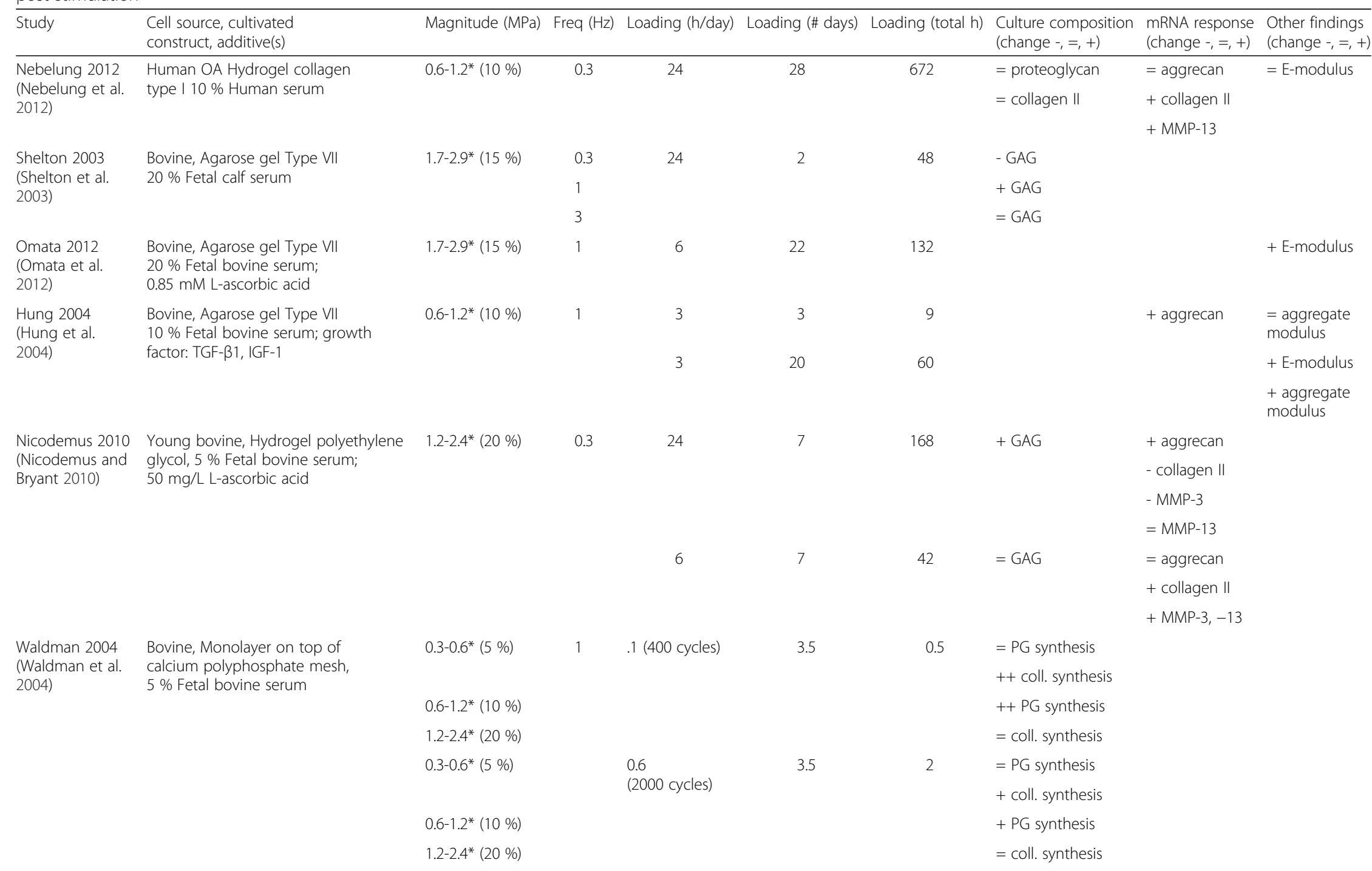


Table 4 Results on changes in cellular, signaling and/or mechanical response to chondrocyte cultivated constructs for direct compression (Fig. 2). OA is osteoarthritis; MMP is matrix metalloproteinases; PG is proteoglycan; $h$ is hours; $h /$ day is hours per day; - is decrease or inhibition; + is increase; ++ is highest increase; $=$ is no change or status quo. ${ }^{*}$-symbol implies pressure converted from strain, which is added in brackets, ${ }^{* *}$-symbol is increase only present $12 \mathrm{~h}$ post stimulation, $\wedge$-symbol is increase only present after $6 \mathrm{~h}$ post stimulation (Continued)

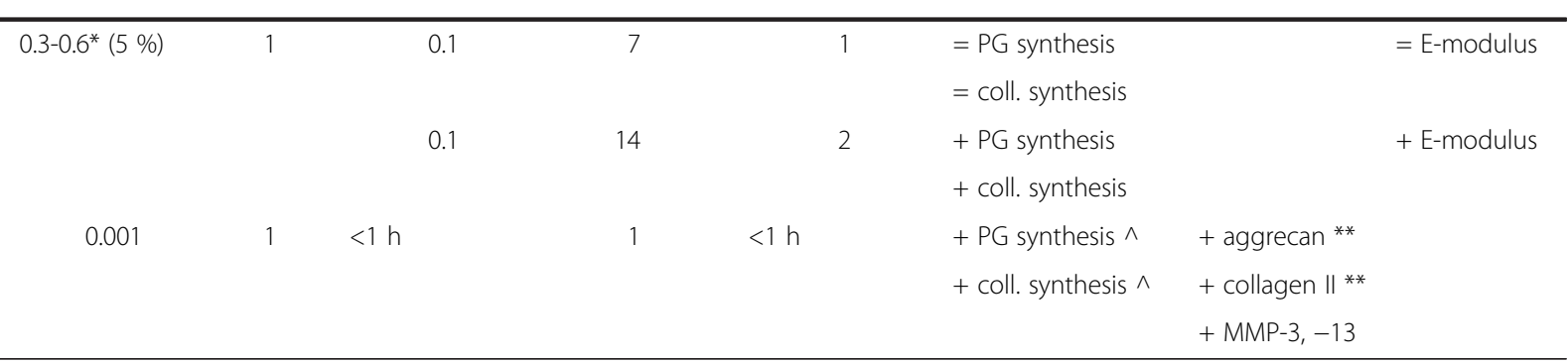

De Croos 2006

(De Croos et al.

2006) 
Table 5 Results on changes in cellular and/or signaling response to BMMSC cultivated constructs under hydrostatic compression (Fig. 2). Sox9 is the gene that regulates chondrogenic differentiation; h is hours; h/day is hours per day; - is decrease or inhibition; and + is increase; ++ is highest increase; = is no change or status quo

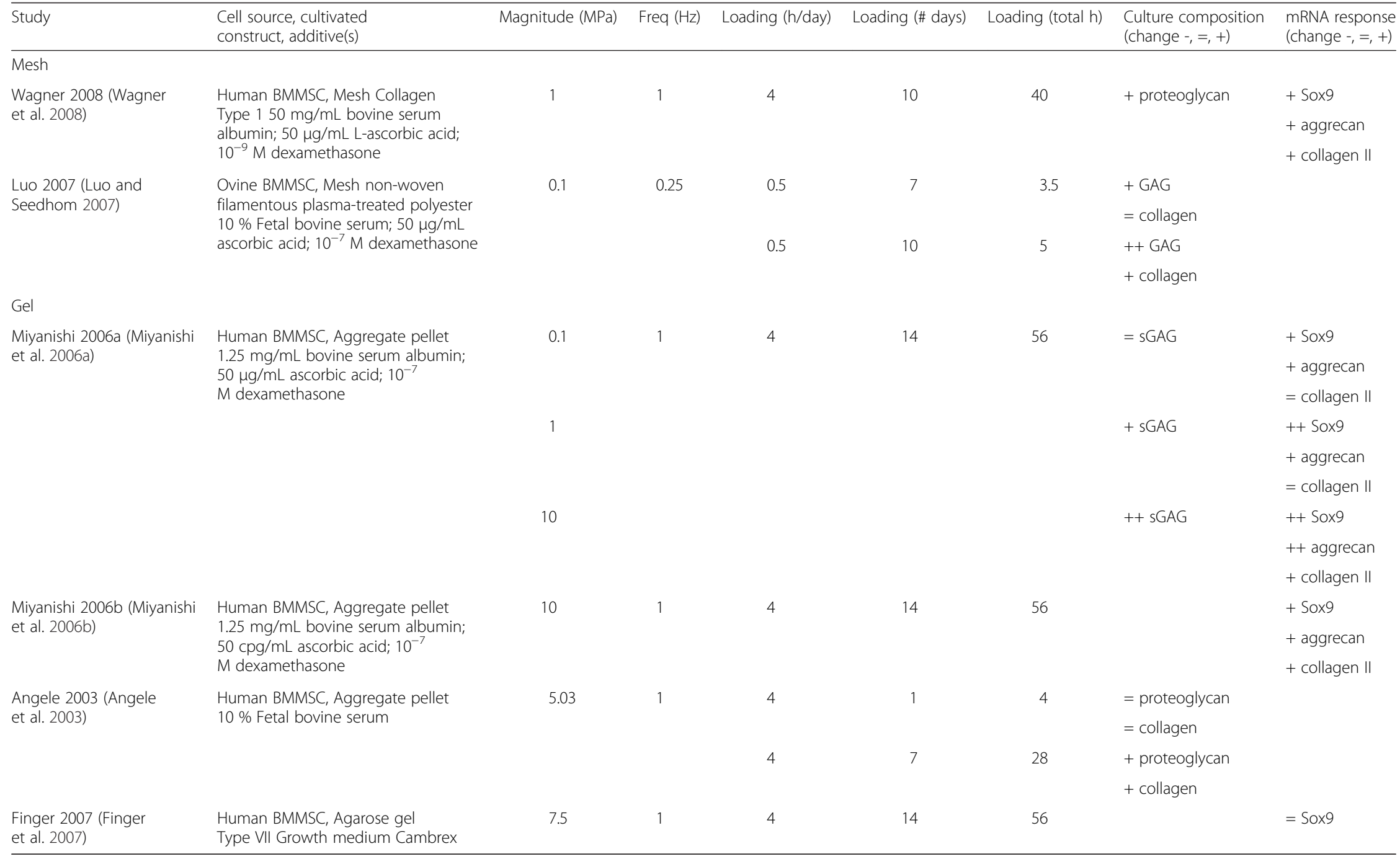


Bader 2007; Spiller et al. 2011). Four different constructs were used to culture chondrocytes: a) explants, which consist of a complete section of cartilage that is excised from a cadaver and embedded in a culture medium (Parkkinen et al. 1993) (Table 1), b) tissue engineered meshes that have a structural 3D shape (Table 2), c) monolayers that consist of isolated chondrocytes from full thickness pieces of cartilage seeded onto a plate (Jortikka et al. 2000; Smith et al. 2000) (Tables 3-4), d) hydrogels that have a softer structure compared to meshes (Carver and Heath 1999b; Hu and Athanasiou 2006) (Tables 3-4). One study used serum free medium (Li et al. 2013), one study added human serum (Nebelung et al. 2012), three added calf serum, and twenty one studies added bovine serum, with thirteen studies also adding L-ascorbic acid and two also adding growth factors in conjunction (Tables 1, 2, 3, 4).

Second, BMMSCs were harvested from bone marrow, and centrifuged to become a pellet culture (Miyanishi et al. 2006a; Kawanishi et al. 2007) (Table 5). Two cultivated constructs were used onto which BMMSCs were seeded : a) a gel or pellet composition and b) tissue engineered meshes (Luo and Seedhom 2007; Wagner et al. 2008) (Table 5). Bovine serum was added in five out of 6 studies, with four studies also adding $50 \mu \mathrm{g} / \mathrm{mL} \mathrm{L}$-ascorbic acid and dexamethasone.

\section{Loading regime}

Two types of cyclic compression were applied: hydrostatic or direct compression (Fig. 2). Hydrostatic pressure is applied by compressing the fluid surrounding the tested culture with a piston (Elder and Athanasiou 2009) (Tables 1, 2, 3 and 5). Direct compression implies that a piston directly presses on the tissue, which is commonly expressed in percentage of strain (Demarteau et al. 2003) (Tables 1,2 and 4). Except the studies by Torzelli et al.
(Torzilli et al. 1996; Torzilli et al. 2011) and De Croos et al. (De Croos et al. 2006), all other eleven studies required conversion from strain to pressure (Tables 1, 2 and 4).

The loading magnitude, frequency and regime varied highly. For example Carver and Heath stimulated their samples with $6.9 \mathrm{MPa}$ at $0.25 \mathrm{~Hz}$ for $2 \mathrm{~h}$ per day over a period of 35 days (Carver and Heath 1999b), while Démarteau et al. applied a loading of $5 \%$ of strain with $0.1 \mathrm{~Hz}$ for $4 \mathrm{~h}$ per day over a period of 3 days (Démarteau et al. 2003). In contrast to this, five out of six studies with human derived BMMSC used $1 \mathrm{~Hz}$ as loading frequency for $4 \mathrm{~h}$ per day (Table 5) (Angele et al. 2003; Miyanishi et al. 2006a, 2006b; Finger et al. 2007; Wagner et al. 2008).

\section{Cartilage cellular, signaling and mechanical response parameters}

Three types of methods were found to document cartilage quality response: cellular, signaling, and mechanical responses (Tables 1, 2, 3, 4,5). Cellular response is routinely determined with histology, which allows identification of specific (macro) molecules that typically represent healthy cartilage (proteoglycans, glucosaminoglycans (GAGs) and sulfated glucosaminoglycans (sGAGs), collagen type II). An increase of proteoglycans is typically determined using staining with Safranin O (Darling and Athanasiou 2003; Schulz and Bader 2007). Similarly, the increase of GAGs and sGAGs is determined with dimethylmethylene blue assay staining (Farndale et al. 1986; Carver and Heath 1999b; Shelton et al. 2003; Heyland et al. 2006; Hilz et al. 2014). The increase in collagens is determined by staining with Picrosirius red, Masson's trichrome stain, or antibody-staining such as anti-collagen antibodies or monoclonal antibodies, and/or the use of polarized light (Angele et al. 2003; Darling and Athanasiou 2003; Heyland et al. 2006; Elder and Athanasiou 2008; Nicodemus and Bryant 2010). After staining, the histologic samples

Hydrostatic compression Direct compression

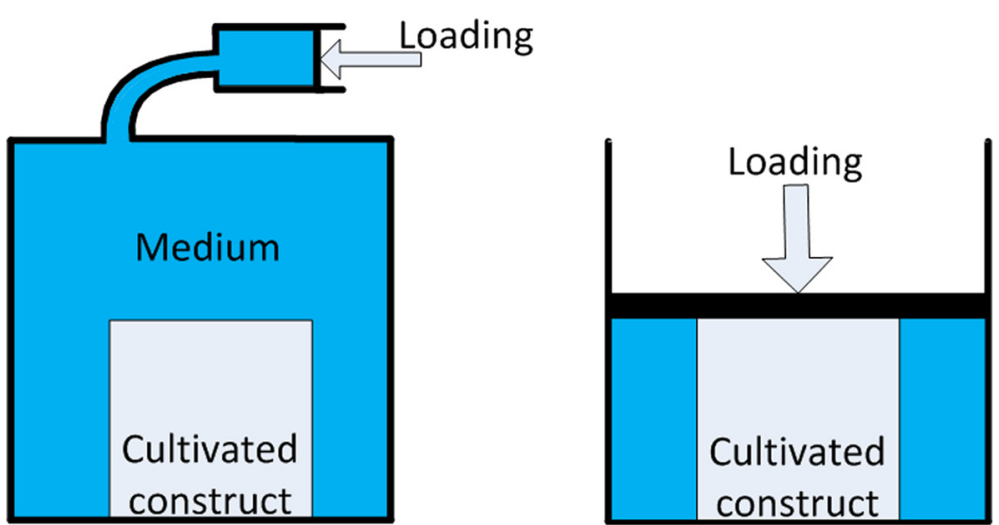

Fig. 2 Difference between hydrostatic compression (left) and direct compression (right). The arrows indicate the loading direction 
are further interpreted with histologic scores and compared to control samples to indicate relative cellular responses. The type of collagen is assessed with immunohistochemistry (Elder and Athanasiou 2008). Finally, cellular response in the form of proteoglycan synthesis is routinely determined by assessing the radioactive labeled ${ }^{35}$ Sulfate-uptake by the proteoglycans (Parkkinen et al. 1993; Torzilli et al. 2011; Li et al. 2013).

Signaling response indirectly indicates the potential of the cells to (de)differentiate into cartilage, because it assesses changes in the level of mRNA expression as produced by the chondrocyte cells with a reverse transcription polymerase chain reaction (RT-PCR) (Darling and Athanasiou 2003; Schulz and Bader 2007). A change in proteoglycan production is commonly documented as an increase in aggrecan mRNA that is the core protein backbone to which GAGs chains are attached (Tables 1 , 2, 3, 4) (Démarteau et al. 2003; Ikenoue et al. 2003; Schulz and Bader 2007). With the same method other relevant expressions are assessed: collagen type II, the gene sex determining region box 9 (Sox9) and Matrix metalloproteinases (MMP). Sox9 is indicative for the regulation of chondrogenic differentiation and plays a role in expression of collagen type II and aggrecan (Démarteau et al. 2003; Miyanishi et al. 2006a; Finger et al. 2007; Wagner et al. 2008; Hilz et al. 2014). MMP plays a major role in ECM turnover and degradation (Hilz et al. 2014). MMP-3 has shown to be a key player in degrading matrix and inactivating other degrading enzymes (Cawston and Wilson 2006; Echtermeyer et al. 2009), and MMP-13 seems to influence the progress of osteoarthritis (Hilz et al. 2014).

Mechanical responses were documented by compression tests of the samples and determining the Young's (or E-) modulus from the linear range of the stressstrain curve (Carver and Heath 1999b; Hung et al. 2004; Heyland et al. 2006; Hu and Athanasiou 2006; Elder and Athanasiou 2008; Omata et al. 2012). Cartilage quality response was given as change of cellular response (including synthesis) by 27 of 33 studies, as change of signaling response by 21 of 33 studies, and as change of mechanical response by 9 of 33 studies.

\section{Responses to mechanical stimuli}

Due to the difference in cell sources, cultivated constructs, compression and outcome measures only qualitative comparison could be performed. Bovine explant testing mimics the in vivo case most closely especially the study by Li et al. (Li et al. 2013), since they used bruised explants (Table 1). The studied variations in the loading regime of the explants suggest a certain threshold for the magnitude of loading ( $>10 \%$ or $>1.2 \mathrm{MPa}$ ) and the frequency $(>0.5 \mathrm{~Hz})$ to stimulate increased proteoglycan synthesis (Table 1). Only Okuda et al. (Okuda et al. 2013) confirmed that this was correlated to increased mechanical response. Studies that tested equine chondrocyte-seeded meshes by hydrostatic compression support the need for a loading threshold (Table 2), since increased cell density was observed by higher loading magnitudes and correlated to increased mechanical response (Carver and Heath 1999b). The three studies of chondrocyte-seeded meshes by direct compression presented too much variation to point in a specific loading regime (Table 2).

The studies that use monolayer and gel cultivated constructs and test variations in loading magnitude, frequency or loading regime (Tables 3-4) also suggest the need for thresholds in magnitude and frequency with a trend towards higher values (up to 5-10 MPa and up to $1 \mathrm{~Hz}$ ) compared to the explant studies to achieve increased responses (Parkkinen et al. 1993; Smith et al. 2000; Ikenoue et al. 2003; Shelton et al. 2003; Waldman et al. 2004; Elder and Athanasiou 2008). Tables 3-4 also highlight the effect of different loading regimes, which seems to suggest that prolonged duration and loading at intervals (no continuous intermittent loading) increase cell density and synthesis, signaling response as well as mechanical response (e.g. (Shelton et al. 2003; Hung et al. 2004)). Exceptions are the studies by De Croos (De Croos et al. 2006) who find increased response at a low magnitude of $0.001 \mathrm{MPa}$ applied for less than $1 \mathrm{~h}$, and by $\mathrm{Hu}$ and Athanasiou ( $\mathrm{Hu}$ and Athanasiou 2006) who did not find a change in the E-modulus after prolonged loading for $160 \mathrm{~h}$.

The studies using BMMSCs as cell source support the suggestion that the largest increase in cellular and signaling response is achieved for larger loading magnitudes $(>5 \mathrm{MPa}$ ) at a frequency of $1 \mathrm{~Hz}$ for a prolonged period (>7 days) at intermittent intervals (Table 5). However, no mechanical responses were measured for these constructs.

\section{Discussion}

Five studies mimicked the in vivo case most closely by testing bovine explants. Only two of these varied the loading magnitude or frequency, which suggest the need of a certain threshold $(>20 \%$ strain and $>0.5 \mathrm{~Hz}$ ) for increased proteoglycan synthesis (Table 1 ). A careful qualitative interpretation of the results suggests that for chondrocyteseeded cultivated constructs a loading pressure between 5-10 $\mathrm{MPa}$ and a loading frequency of $1 \mathrm{~Hz}$ exerted at intermittent intervals for a period of a week or longer are recommended as appropriate mechanical stimulus. These values are in the physiologic range of normal gait (Waters et al. 1988; Giddings et al. 2000; Brand 2005; Doke et al. 2005; van Dijk et al. 2010a). Due to the variety of testing conditions and methods to express cartilage quality response, only qualitative comparison was possible, which poses limitations to the study. First, differences in sample tissue, sample preparation, donor type and donor age all accounted for differences in the outcome of these studies 
(Parkkinen et al. 1993; Carver and Heath 1999a; Darling and Athanasiou 2003; Chung and Burdick 2008). Still, fourteen of the 33 studies did measure the cartilage quality response to varying loading parameters within the same set up. Even though, signaling response does not always reflect actual cellular and mechanical changes, the studies that report them also report cellular and/or mechanical response in conjunction (Tables 2, 3, 4, 5), with in the majority of the cases showing corresponding in- or decreases. With this, the decision was made to include studies that only present signaling response (four in total), since two have varied the loading regime (intermittent vs continuous loading (Smith et al. 2000); and loading magnitude and duration (Ikenoue et al. 2003)) as needed to answer our main research question (Table 3). Second, two different types of compression were applied: hydrostatic (Tables 1, 2, 3 and 5) and direct compression (Tables 1,2 and 4). There is an on-going debate which type of loading is more physiological. Some are in favor of direct compression (Buschmann et al. 1995; Mauck et al. 2000; Waldman et al. 2004). Also, direct compression allows continuous measurement of mechanical responses, but needs some tricks to be applied to soft constructs by placing the samples in bags (De Croos et al. 2006). Bachrach et al. (Bachrach et al. 1998) suggest that hydrostatic pressure seems to be more representative for the in vivo loading case, because it mimics the viscoelastic multiphasic cartilage behavior closest. A drawback is that it also stimulates the sides of the samples. An advantage of applying hydrostatic compression is that it allows for harmonization of the applied load, and it allows mechanical stimulation of different types of cultivated constructs including the softer ones. The proposed transformation procedure from strain to pressure seems to make sense, because the calculated pressure values are in line with the values found in other studies: $3.6 \mathrm{MPa}$ leads to a $29 \%$ strain (Herberhold et al. 1999) vs $20 \%$ strain (Hilz et al. 2014) (Tables 2 and 4). However, it still remains an approximation, which needs to be interpreted with care. Third, biologic demonstration of the increase in cartilage quality response is highly important, since it indicates parameters (signals, cells types, cell synthesis) that should be triggered to stimulate the cell activity and behave like cartilage. However, documentation of actual mechanical response would be expected as well, since this determines performance. In one quarter of the studies (9 out of 33) the mechanical response was measured, which is a rather low percentage. Some of the cultivated constructs (monolayer, pellet) do not resemble the actual ECM structure, which makes mechanical testing difficult or impossible (Tables 1, 2, 3, 4, 5). Full characterization is difficult, because of its highly complex viscoelastic behavior (Mow et al. 1999; Schulz and Bader 2007; Khan and Scott 2009; Madry et al. 2010). Furthermore, constructs can also change due to the loading or do not necessarily mimic mechanical cartilage behavior (Nebelung et al. 2011). This latter is supported by conflicting results that were found for two studies in which agarose gel was used: $\mathrm{Hu}$ and Athanasiou ( $\mathrm{Hu}$ and Athanasiou 2006) show that a $20 \%$ increase in collagen type II does not seem to influence the mechanical properties (Table 3), and others (Hung et al. 2004; Elder and Athanasiou 2008; Omata et al. 2012) did not find a relation between histologic and mechanical parameters.

In vivo tissue engineering cartilage repair techniques (e.g. Matrix-Induced Autologous Chondrocyte Implantation or cell-seeded hydrogel plugs (Brittberg 2010; Fortier et al. 2011; Hildner et al. 2011; Spiller et al. 2011)) make use of similar scaffolds. This review gives a summary of current evidence, which can be used for future development of on in vivo application rehabilitation protocol. Several factors are fundamentally different for the in vivo case, including the fact that the ECM is not intact as result of the cartilage lesion, and that the access to essential biologicals (e.g. cytokines, growth factors) is different in the physiologic situation compared to the in vitro situation. Especially, the boundary between the healthy cartilage and tissue engineered scaffold is a vulnerable spot (Khan et al. 2008), which most likely cannot withstand the suggested loading magnitude (Guettler et al. 2004; Khan et al. 2008; van Dijk et al. 2010a, 2010b; Spiller et al. 2011; Hunt et al. 2012). However, the results could be used to optimize preconditioning of tissue engineered scaffolds before implantation into patients (Shelton et al. 2003; Nebelung et al. 2012; Omata et al. 2012). Therefore, the timing of loading could be a critical factor that needs to be further explored. For example the testing period might be even further extended (Waldman et al. 2004), since in vivo studies with animal models evaluated the cartilage quality response after long testing periods (56 days or longer), much longer than those found in this review (Saris et al. 2003; Kok et al. 2013; Miller et al. 2014; Ortved et al. 2015). Finally, studying the dynamic compression of damaged explants (e.g. (Li et al. 2013)), should be elaborated to identify the best magnitude, frequency and loading regime, since these constructs mimic the in vivo cartilage lesion closest. This will facilitate the translation of the found combination of mechanical parameters to patients.

\section{Conclusions}

Overall, the results seem to suggest that a certain threshold exits for enhanced cartilage in vitro cultivation of explants, and that chondrocyte-seeded cultivated constructs show best results when loaded with physiological mechanical stimuli. This seems a reasonable conclusion, because nature is highly optimized for daily activities such as normal walking. Critical aspects remain to be answered for translation of the results into in vivo therapies. 


\section{Competing interests}

The authors declare that they have no competing interests.

\section{Authors' contributions}

JN, GT: have made substantial contributions to conception and design, or acquisition of data, or analysis and interpretation of data; JN, AK, JD, GT: have been involved in drafting the manuscript or revising it critically for important intellectual content; AK, JD, GT: have given final approval of the version to be published.

\section{Received: 7 April 2015 Accepted: 26 May 2015}

\section{Published online: 19 June 2015}

\section{References}

Angele P, Yoo JU, Smith C, Mansour J, Jepsen KJ, Nerlich M, Johnstone B (2003) Cyclic hydrostatic pressure enhances the chondrogenic phenotype of human mesenchymal progenitor cells differentiated in vitro. J Orthop Res 21(3):451-457

Arokoski JP, Jurvelin JS, Vaatainen U, Helminen HJ (2000) Normal and pathological adaptations of articular cartilage to joint loading. Scand J Med Sci Sports 10(4):186-198

Bachrach NM, Mow VC, Guilak F (1998) Incompressibility of the solid matrix of articular cartilage under high hydrostatic pressures. J Biomech 31(5):445-451

Bahuleyan B, Cheung HS, Huang CYC (2009) Role of biomechanical force in stem cell-based therapy for cartilage repair. Curr Rheumatol Rev 5(1):34-39

Bonassar L, Grodzinsky AJ, Frank EH, Davila SG, Bhaktav NR, Trippel SB (2001) The effect of dynamic compression on the response of articular cartilage to insulin-like growth factor-I. J Orthop Res 19(1):11-17

Brand RA (2005) Joint contact stress: a reasonable surrogate for biological processes? lowa Orthop J 25:82-94

Brittberg M (2010) Cell carriers as the next generation of cell therapy for cartilage repair: a review of the matrix-induced autologous chondrocyte implantation procedure. Am J Sports Med 38(6):1259-1271

Buckwalter JA, Mankin HJ (1998) Articular cartilage: tissue design and chondrocyte-matrix interactions. Instr Course Lect 47:477-486

Buschmann MD, Gluzband YA, Grodzinsky AJ, Hunziker EB (1995) Mechanical compression modulates matrix biosynthesis in chondrocyte/agarose culture. J Cell Sci 108(Pt 4):1497-1508

Carver SE, Heath CA (1999a) Increasing extracellular matrix production in regenerating cartilage with intermittent physiological pressure. Biotechnol Bioeng 62(2):166-174

Carver SE, Heath CA (1999b) Influence of intermittent pressure, fluid flow, and mixing on the regenerative properties of articular chondrocytes. Biotechnol Bioeng 65(3):274-281

Cawston TE, Wilson AJ (2006) Understanding the role of tissue degrading enzymes and their inhibitors in development and disease. Best Pract Res Clin Rheumatol 20(5):983-1002

Chu CR, Szczodry M, Bruno S (2010) Animal models for cartilage regeneration and repair. Tissue Eng Part B Rev 16(1):105-115

Chung C, Burdick JA (2008) Engineering cartilage tissue. Adv Drug Deliv Rev 60(2):243-262

Cohen NP, Foster RJ, Mow VC (1998) Composition and dynamics of articular cartilage: structure, function, and maintaining healthy state. J Orthop Sports Phys Ther 28(4):203-215

Darling EM, Athanasiou KA (2003) Biomechanical strategies for articular cartilage regeneration. Ann Biomed Eng 31(9):1114-1124

De Croos JN, Dhaliwal SS, Grynpas MD, Pilliar RM, Kandel RA (2006) Cyclic compressive mechanical stimulation induces sequential catabolic and anabolic gene changes in chondrocytes resulting in increased extracellular matrix accumulation. Matrix biology : journal of the International Society for Matrix Biology 25(6):323-331

Demarteau O, Jakob M, Schafer D, Heberer M, Martin I (2003) Development and validation of a bioreactor for physical stimulation of engineered cartilage. Biorheology 40(1-3):331-336

Démarteau O, Wendt D, Braccini A, Jakob M, Schäfer D, Heberer M, Martin I (2003) Dynamic compression of cartilage constructs engineered from expanded human articular chondrocytes. Biochem Biophys Res Commun 310(2):580-588

Doke J, Donelan JM, Kuo AD (2005) Mechanics and energetics of swinging the human leg. J Exp Biol 208(Pt 3):439-445

Echtermeyer F, Bertrand J, Dreier R, Meinecke I, Neugebauer K, Fuerst M, Lee YJ, Song YW, Herzog C, Theilmeier G, Pap T (2009) Syndecan-4 regulates
ADAMTS-5 activation and cartilage breakdown in osteoarthritis. Nat Med 15(9):1072-1076

El-Ayoubi R, DeGrandpre C, DiRaddo R, Yousefi AM, Lavigne P (2011) Design and dynamic culture of 3D-scaffolds for cartilage tissue engineering. J Biomater Appl 25(5):429-444

Elder BD, Athanasiou KA (2008) Synergistic and additive effects of hydrostatic pressure and growth factors on tissue formation. PLoS One 3(6), e2341

Elder BD, Athanasiou KA (2009) Hydrostatic pressure in articular cartilage tissue engineering: from chondrocytes to tissue regeneration. Tissue Eng Part B Rev 15(1):43-53

Fan JC, Waldman SD (2010) The effect of intermittent static biaxial tensile strains on tissue engineered cartilage. Ann Biomed Eng 38(4):1672-1682

Farndale RW, Buttle DJ, Barrett AJ (1986) Improved quantitation and discrimination of sulphated glycosaminoglycans by use of dimethylmethylene blue. Biochim Biophys Acta 883(2):173-177

Finger AR, Sargent CY, Dulaney KO, Bernacki SH, Loboa EG (2007) Differential effects on messenger ribonucleic acid expression by bone marrow-derived human mesenchymal stem cells seeded in agarose constructs due to ramped and steady applications of cyclic hydrostatic pressure. Tissue Eng 13(6):1151-1158

Fortier LA, Barker JU, Strauss EJ, McCarrel TM, Cole BJ (2011) The role of growth factors in cartilage repair. Clin Orthop Relat Res 469(10):2706-2715

Giddings VL, Beaupre GS, Whalen RT, Carter DR (2000) Calcaneal loading during walking and running. Med Sci Sports Exerc 32(3):627-634

Grodzinsky AJ, Levenston ME, Jin M, Frank EH (2000) Cartilage tissue remodeling in response to mechanical forces. Annu Rev Biomed Eng 2:691-713

Guettler JH, Demetropoulos CK, Yang KH, Jurist KA (2004) Osteochondral defects in the human knee: influence of defect size on cartilage rim stress and load redistribution to surrounding cartilage. Am J Sports Med 32(6):1451-1458

Hannon CP, Smyth NA, Murawski CD, Savage-Elliott I, Deyer TW, Calder JD, Kennedy JG (2014) Osteochondral lesions of the talus: aspects of current management. The bone \& joint journal 96-B(2):164-171

Heath CA, Magari SR (1996) Mini-review: Mechanical factors affecting cartilage regeneration in vitro. Biotechnol Bioeng 50(4):430-437

Herberhold C, Faber S, Stammberger T, Steinlechner M, Putz R, Englmeier KH, Reiser M, Eckstein F (1999) In situ measurement of articular cartilage deformation in intact femoropatellar joints under static loading. J Biomech 32(12):1287-1295

Hess R, Douglas T, Myers KA, Rentsch B, Rentsch C, Worch H, Shrive NG, Hart DA, Scharnweber D (2010) Hydrostatic pressure stimulation of human mesenchymal stem cells seeded on collagen-based artificial extracellular matrices. J Biomech Eng 132(2):021001

Heyland J, Wiegandt K, Goepfert C, Nagel-Heyer S, llinich E, Schumacher U, Portner R (2006) Redifferentiation of chondrocytes and cartilage formation under intermittent hydrostatic pressure. Biotechnol Lett 28(20):1641-1648

Hildner F, Albrecht C, Gabriel C, Redl H, van Griensven M (2011) State of the art and future perspectives of articular cartilage regeneration: a focus on adipose-derived stem cells and platelet-derived products. J Tissue Eng Regen Med 5(4):e36-51

Hilz FM, Ahrens P, Grad S, Stoddart MJ, Dahmani C, Wilken FL, Sauerschnig M, Niemeyer $P$, Zwingmann J, Burgkart R, von Eisenhart-Rothe R, Südkamp NP Weyh T, Imhoff AB, Alini M, Salzmann GM (2014) Influence of extremely low frequency, low energy electromagnetic fields and combined mechanical stimulation on chondrocytes in 3-D constructs for cartilage tissue engineering. Bioelectromagnetics 35(2):116-128

$\mathrm{Hu}$ JC, Athanasiou KA (2006) The effects of intermittent hydrostatic pressure on self-assembled articular cartilage constructs. Tissue Eng 12(5):1337-1344

Hung CT, Mauck RL, Wang CC, Lima EG, Ateshian GA (2004) A paradigm for functional tissue engineering of articular cartilage via applied physiologic deformational loading. Ann Biomed Eng 32(1):35-49

Hunt KJ, Lee AT, Lindsey DP, Slikker W 3rd, Chou LB (2012) Osteochondral lesions of the talus: effect of defect size and plantarflexion angle on ankle joint stresses. Am J Sports Med 40(4):895-901

Ikenoue T, Trindade MCD, Lee MS, Lin EY, Schurman DJ, Goodman SB, Smith RL (2003) Mechanoregulation of human articular chondrocyte aggrecan and type II collagen expression by intermittent hydrostatic pressure in vitro. J Orthop Res 21(1):110-116

Jortikka MO, Parkkinen JJ, Inkinen RI, Karner J, Jarvelainen HT, Nelimarkka LO, Tammi MI, Lammi MJ (2000) The role of microtubules in the regulation of proteoglycan synthesis in chondrocytes under hydrostatic pressure. Arch Biochem Biophys 374(2):172-180 
Kawanishi M, Oura A, Furukawa K, Fukubayashi T, Nakamura K, Tateishi T, Ushida $\mathrm{T}$ (2007) Redifferentiation of dedifferentiated bovine articular chondrocytes enhanced by cyclic hydrostatic pressure under a gas-controlled system. Tissue Eng 13(5):957-964

Khan IM, Gilbert SJ, Singhrao SK, Duance VC, Archer CW (2008) Cartilage integration: evaluation of the reasons for failure of integration during cartilage repair. A review. Eur Cell Mater 16:26-39

Khan KM, Scott A (2009) Mechanotherapy: how physical therapists' prescription of exercise promotes tissue repair. Br J Sports Med 43(4):247-252

Kok AC, Tuijthof GJ, den Dunnen S, van Tiel J, Siebelt M, Everts V, van Dijk CN, Kerkhoffs GM (2013) No effect of hole geometry in microfracture for talar osteochondral defects. Clin Orthop Relat Res 471(11):3653-3662

Li Y, Frank EH, Wang Y, Chubinskaya S, Huang HH, Grodzinsky AJ (2013) Moderate dynamic compression inhibits pro-catabolic response of cartilage to mechanical injury, tumor necrosis factor-a and interleukin-6, but accentuates degradation above a strain threshold. Osteoarthritis Cartilage 21(12):1933-1941

Luo ZJ, Seedhom BB (2007) Light and low-frequency pulsatile hydrostatic pressure enhances extracellular matrix formation by bone marrow mesenchymal cells: an in-vitro study with special reference to cartilage repair Proc Inst Mech Eng H J Eng Med 221(5):499-507

Madry H, Grün UW, Knutsen G (2011) Cartilage repair and joint preservation: Medical and surgical treatment options. Deutsches Arzteblatt 108(40):669-677

Madry H, van Dijk CN, Mueller-Gerbl M (2010) The basic science of the subchondral bone. Knee surgery, sports traumatology, arthroscopy: official journal of the ESSKA 18(4):419-433

Magnussen RA, Dunn WR, Carey JL, Spindler KP (2008) Treatment of focal articular cartilage defects in the knee: a systematic review. Clin Orthop Relat Res 466(4):952-962

Mauck RL, Nicoll SB, Seyhan SL, Ateshian GA, Hung CT (2003) Synergistic action of growth factors and dynamic loading for articular cartilage tissue engineering. Tissue Eng 9(4):597-611

Mauck RL, Soltz MA, Wang CC, Wong DD, Chao PH, Valhmu WB, Hung CT, Ateshian GA (2000) Functional tissue engineering of articular cartilage through dynamic loading of chondrocyte-seeded agarose gels. J Biomech Eng 122(3):252-260

Meachim G, Stockwell RA (1973) The Matrix. Freeman MA (ed) Adult articular cartilage. Pitman medical, London, pp 1-5.

Miller RE, Grodzinsky AJ, Barrett MF, Hung HH, Frank EH, Werpy NM, Mcllwraith CW, Frisbie DD (2014) Effects of the combination of microfracture and self-assembling Peptide filling on the repair of a clinically relevant trochlear defect in an equine model. J Bone Joint Surg Am 96(19):1601-1609

Miyanishi K, Trindade MC, Lindsey DP, Beaupre GS, Carter DR, Goodman SB, Schurman DJ, Smith RL (2006a) Dose- and time-dependent effects of cyclic hydrostatic pressure on transforming growth factor-beta3-induced chondrogenesis by adult human mesenchymal stem cells in vitro. Tissue Eng 12(8):2253-2262

Miyanishi K, Trindade MC, Lindsey DP, Beaupre GS, Carter DR, Goodman SB, Schurman DJ, Smith RL (2006b) Effects of hydrostatic pressure and transforming growth factor-beta 3 on adult human mesenchymal stem cell chondrogenesis in vitro. Tissue Eng 12(6):1419-1428

Mizuno S, Ogawa R (2011) Using changes in hydrostatic and osmotic pressure to manipulate metabolic function in chondrocytes. Am J Physiol Cell Physiol 300(6):C1234-1245

Mow VC, Wang CC, Hung CT (1999) The extracellular matrix, interstitial fluid and ions as a mechanical signal transducer in articular cartilage. Osteoarthritis and cartilage / OARS, Osteoarthritis Research Society 7(1):41-58

Nebelung S, Gavenis K, Luring C, Zhou B, Mueller-Rath R, Stoffel M, Tingart M, Rath B (2012) Simultaneous anabolic and catabolic responses of human chondrocytes seeded in collagen hydrogels to long-term continuous dynamic compression. Annals of anatomy = Anatomischer Anzeiger: official organ of the Anatomische Gesellschaft 194(4):351-358

Nebelung S, Gavenis K, Rath B, Tingart M, Ladenburger A, Stoffel M, Zhou B, Mueller-Rath R (2011) Continuous cyclic compressive loading modulates biological and mechanical properties of collagen hydrogels seeded with human chondrocytes. Biorheology 48(5):247-261

Nicodemus GD, Bryant SJ (2010) Mechanical loading regimes affect the anabolic and catabolic activities by chondrocytes encapsulated in PEG hydrogels. Osteoarthritis Cartilage 18(1):126-137

Okuda Y, Konishi R, Miyata S (2013) Effect of cyclic compressive stimuli on mechanical anisotropy of chondrocyte-seeded agarose gel culture. Nihon Kikai Gakkai Ronbunshu, C Hen/Transactions of the Japan Society of Mechanical Engineers, Part C 79(801):1736-1743
Omata S, Sonokawa S, Sawae Y, Murakami T (2012) Effects of both vitamin C and mechanical stimulation on improving the mechanical characteristics of regenerated cartilage. Biochem Biophys Res Commun 424(4):724-729

Ortved KF, Begum L, Mohammed HO, Nixon AJ (2015) Implantation of rAAV5IGF-I Transduced Autologous Chondrocytes Improves Cartilage Repair in Full-thickness Defects in the Equine Model. Molecular therapy: the journal of the American Society of Gene Therapy 23(2):363-373

Parkkinen JJ, Ikonen J, Lammi MJ, Laakkonen J, Tammi M, Helminen HJ (1993) Effects of cyclic hydrostatic pressure on proteoglycan synthesis in cultured chondrocytes and articular cartilage explants. Arch Biochem Biophys 300(1):458-465

Potier E, Noailly J, Ito K (2010) Directing bone marrow-derived stromal cell function with mechanics. J Biomech 43(5):807-817

Saris DB, Dhert WJ, Verbout AJ (2003) Joint homeostasis. The discrepancy between old and fresh defects in cartilage repair. J Bone Joint Surg 85(7):1067-1076

Schulz RM, Bader A (2007) Cartilage tissue engineering and bioreactor systems for the cultivation and stimulation of chondrocytes. European biophysics journal : EBJ 36(4-5):539-568

Shelton JC, Bader DL, Lee DA (2003) Mechanical conditioning influences the metabolic response of cell-seeded constructs. Cells Tissues Organs 175(3):140-150

Shepherd DE, Seedhom BB (1999) The 'instantaneous' compressive modulus of human articular cartilage in joints of the lower limb. Rheumatology (Oxford) 38(2):124-132

Smith RL, Lin J, Trindade MC, Shida J, Kajiyama G, Vu T, Hoffman AR, van der Meulen MC, Goodman SB, Schurman DJ, Carter DR (2000) Time-dependent effects of intermittent hydrostatic pressure on articular chondrocyte type II collagen and aggrecan mRNA expression. J Rehabil Res Dev 37(2):153-161

Smith RL, Rusk SF, Ellison BE, Wessells P, Tsuchiya K, Carter DR, Caler WE, Sandell $\sqcup$, Schurman DJ (1996) In vitro stimulation of articular chondrocyte mRNA and extracellular matrix synthesis by hydrostatic pressure. J Orthop Res 14(1):53-60

Spiller KL, Maher SA, Lowman AM (2011) Hydrogels for the repair of articular cartilage defects. Tissue Eng Part B Rev 17(4):281-299

Suh JK, Baek GH, Aroen A, Malin CM, Niyibizi C, Evans CH, Westerhausen-Larson A (1999) Intermittent sub-ambient interstitial hydrostatic pressure as a potential mechanical stimulator for chondrocyte metabolism. Osteoarthritis and cartilage / OARS, Osteoarthritis Research Society 7(1):71-80

Torzilli PA, Bhargava M, Chen CT (2011) Mechanical Loading of Articular Cartilage Reduces IL-1-Induced Enzyme Expression. Cartilage 2(4):364-373

Torzilli PA, Tehrany AM, Grigiene R, Young E (1996) Effects of misoprostol and prostaglandin E2 on proteoglycan biosynthesis and loss in unloaded and loaded articular cartilage explants. Prostaglandins 52(3):157-173

van Dijk CN, Reilingh ML, Zengerink M, van Bergen CJ (2010a) The natural history of osteochondral lesions in the ankle. Instr Course Lect 59:375-386

van Dijk CN, Reilingh ML, Zengerink M, van Bergen CJ (2010b) Osteochondral defects in the ankle: why painful? Knee surgery, sports traumatology, arthroscopy : official journal of the ESSKA 18(5):570-580

Wagner DR, Lindsey DP, Li KW, Tummala P, Chandran SE, Smith RL, Longaker MT, Carter DR, Beaupre GS (2008) Hydrostatic pressure enhances chondrogenic differentiation of human bone marrow stromal cells in osteochondrogenic medium. Ann Biomed Eng 36(5):813-820

Waldman SD, Spiteri CG, Grynpas MD, Pilliar RM, Kandel RA (2004) Long-term intermittent compressive stimulation improves the composition and mechanical properties of tissue-engineered cartilage. Tissue Eng 10(9-10):1323-1331

Waters RL, Lunsford BR, Perry J, Byrd R (1988) Energy-speed relationship of walking: standard tables. J Orthop Res 6(2):215-222

Zengerink M, Szerb I, Hangody L, Dopirak RM, Ferkel RD, van Dijk CN (2006) Current concepts: treatment of osteochondral ankle defects. Foot Ankle Clin 11(2):331-359, vi 